\title{
FISH ASSEMBLAGE COMPOSITION IN A TRIBUTARY OF THE MOGI GUAÇU RIVER BASIN, SOUTHEASTERN BRAZIL
}

\author{
Alexandre Kannebley de Oliveira ${ }^{1}$ \\ Júlio César Garavello ${ }^{1}$
}

\begin{abstract}
Fish assemblage composition and seasonal patterns of species abundance were studied in Cabaceiras stream, a tributary of the Mogi Guaçu river in São Paulo State, Brazil. Three stations were sampled monthly from June 1999 to May 2000 using sieves and small trawl net and gill nets. Fifteen fish families, 37 genera and 45 species were captured. Characiformes (27 spp.) and Siluriformes (13 spp.) were the most species-rich orders. Gymnotiformes and Perciformes were represented by two species each, and Synbranchiformes had only a single species. One group of species (approximately $75 \%$ ) persisted in the stream throughout the year. A second group (approximately $25 \%$ ) contained species that only occupy the stream for a limited period of their life cycle, and overall fish assemblage composition was associated with the seasonal flood cycle.
\end{abstract}

KEYWORDS. Fishes, seasonality, stream, Paraná system, Mogi Guaçu river.

\section{INTRODUCTION}

The Mogi Guaçu river of the Paraná system has a well studied fish fauna relative to other drainages in Brazil. Meanwhile, the most available information on fish assemblages comes from the main river channel, or from oxbow lakes in floodplain areas. SCHUBART (1954) and Godoy $(1954,1962)$ associated the seasonal upriver migratory fish movements at Cachoeira de Emas with the species reproductive behaviour. GALETTI et al. (1990) compared the fish community structure of Infernão and Diogo lakes, two oxbow lakes of Mogi Guaçu floodplain, suggesting that these environments constitute natural refuges for young fishes. Trophic ecology of small characids was studied by EsTEVES \& GALETTI (1995) in Infernão lake, and the feeding of the fish community in Diogo lake were reported by Meschiatti (1995).

Information available on biology and ecology of small sized fish species inhabiting streams and small tributaries of the Mogi Guaçu river is scarce. There is no information about fish composition or seasonality on species distribution, as well as on their biological and ecological activities. This scarcity of knowledge is also true for Paraná system, where few studies about stream fishes were carried out. CASTRO \& CASATTI (1997) contributed on

1. Departamento de Ecologia e Biologia Evolutiva, Universidade Federal de São Carlos, Via Washington Luís Km 235, Caixa Postal 676, 13565905, São Carlos, SP, Brasil. (pako@iris.ufscar.br) 
the composition and trophic structure of fish fauna in a forested stream of Pardo, a tributary of Mogi Guaçu river. CASATTI et al. (2001) presented fish species composition in tributaries of Paranapanema, upper Paraná system. PenczaK et al. (1994) analyzed the community structure of two streams and Luiz et al. (1998) studied the trophic ecology of fishes in two other streams of the Paraná floodplain. Seasonality in fish assemblages of distinct streams in Paraná basin were investigated by UIEDA (1984), GARUTTI (1988) and PaVAnelli \& CARAmaschi (1997).

According to Lowe-McConnell (1979) fishes in floodplain systems possess adaptations that allow exploitation of the flood cycle. At the Paraná system, tributaries with low declivity that drains to floodplains areas shelters small sized resident fish species showing seasonality for the large sized species. They exploit these periodically flooded environments for spawning or for feeding activities. This study is an inventory of the fish fauna from Cabaceiras stream, at Mogi Guaçu river floodplain, analyzing the species composition during the seasonal cycle, aiming to identify the resident species and those immigrants species that inhabit the stream only for a period of their life cycle.

\section{MATERIAL AND METHODS}

The Mogi Guaçu river, of the upper Paraná river basin, rises in south Minas Gerais State, at 1,600 $\mathrm{m}$ of altitude, drains through São Paulo State from southeast to northwest direction and flows to the Pardo river, at $470 \mathrm{~m}$ of altitude.

The Cabaceiras stream (fig. 1), with extension of $38 \mathrm{~km}$ and low declivity, rises at $800 \mathrm{~m}$ of altitude in the municipality of São Carlos and drains through areas of farms with a variety of soil uses, as cane plant and Citrus cultures, pastures and remains of "cerrado", the original savanna-like vegetal formation, flowing in a floodplain area of the median Mogi Guaçu river, at the altitude of $510 \mathrm{~m}$. The region is under tropical climate, with two well defined seasons along the year. Dry season ranges from April to September and the wet season begins in October and extends to March. Although the São Paulo State area has been perturbed by diverse anthropic activities, some watercourses, such as Cabaceiras stream, remain relatively unimpacted.

Collect stations of the stream comprising from 150 to $250 \mathrm{~m}$ long, in function of variety of width and depth in each site, were studied during one year, from June 1999 to May 2000, except in October 1999, in order to verify the influence of seasonality in fish fauna. The first station (site 1), at the upper portion of the stream, at $21^{\circ} 49^{\prime} \mathrm{S}$ and $47^{\circ} 57^{\prime} \mathrm{W}, 625 \mathrm{~m}$ of altitude, with $0.1 \mathrm{~m}$ to $1.70 \mathrm{~m}$ maximum depth and $6 \mathrm{~m}$ maximum width, presents small riffles stretches with rocky bottom intercalated by pools of slow water, sandy-clay bottom and fallen vegetable litter. The right margin is occupied by remains of riparian vegetation and the left margin by a pasture with shrubs. The site 2 , located at $21^{\circ} 47^{\prime} \mathrm{S}$ and $47^{\circ} 58^{\prime} \mathrm{W}$, with $609 \mathrm{~m}$ of altitude, presents similar riffles and pools habitats as observed in site 1. Compared to the tributary Olhos d'água creek, located upstream, the site 2 presents greater water volume, ranging from 0.1 to $2.0 \mathrm{~m}$ depth and with $8 \mathrm{~m}$ maximum width. At this site, the Cabaceiras stream flows through a farm with sugar cane plantation and its marginal vegetation includes pasture with shrubs and remains of riparian vegetation on both margins. Site 3, located at $21^{\circ} 42^{\prime} \mathrm{S}$ and $47^{\circ} 57^{\prime} \mathrm{W}$, with $552 \mathrm{~m}$ of altitude, is characterized by higher water volume, including shallow stretches of fast water and deep pools with sand and leaf litter, reaching 2.30 maximum depth and $10 \mathrm{~m}$ maximum width. Its right margin is occupied by pasture and the left margin by riparian vegetation. This site suffered direct influence of the floodplain during the wet season, when their margins were flooded and the aquatic environment was extended, being potentially occupied by fishes and other aquatic organisms.

Monthly pluviometric and air temperature data were obtained in a climatological station located at the Universidade Federal de São Carlos $\left(21^{\circ} 58^{\prime} \mathrm{S}-47^{\circ} 52^{\prime} \mathrm{W}\right)$ and were provided by the INMET (Instituto Nacional de Meteorologia). Total monthly pluviosity and the means of the highest and lowest air temperature registered during the study period are presented in a graph.

Fishes were collected with sieves $(3 \mathrm{~mm}$ mesh) and a small trawl net $(3 \mathrm{~mm}$ mesh) along the sample sites, and with gill nets (15 to $30 \mathrm{~mm}$ mesh size) at the slow water deepest pools. The specimens 


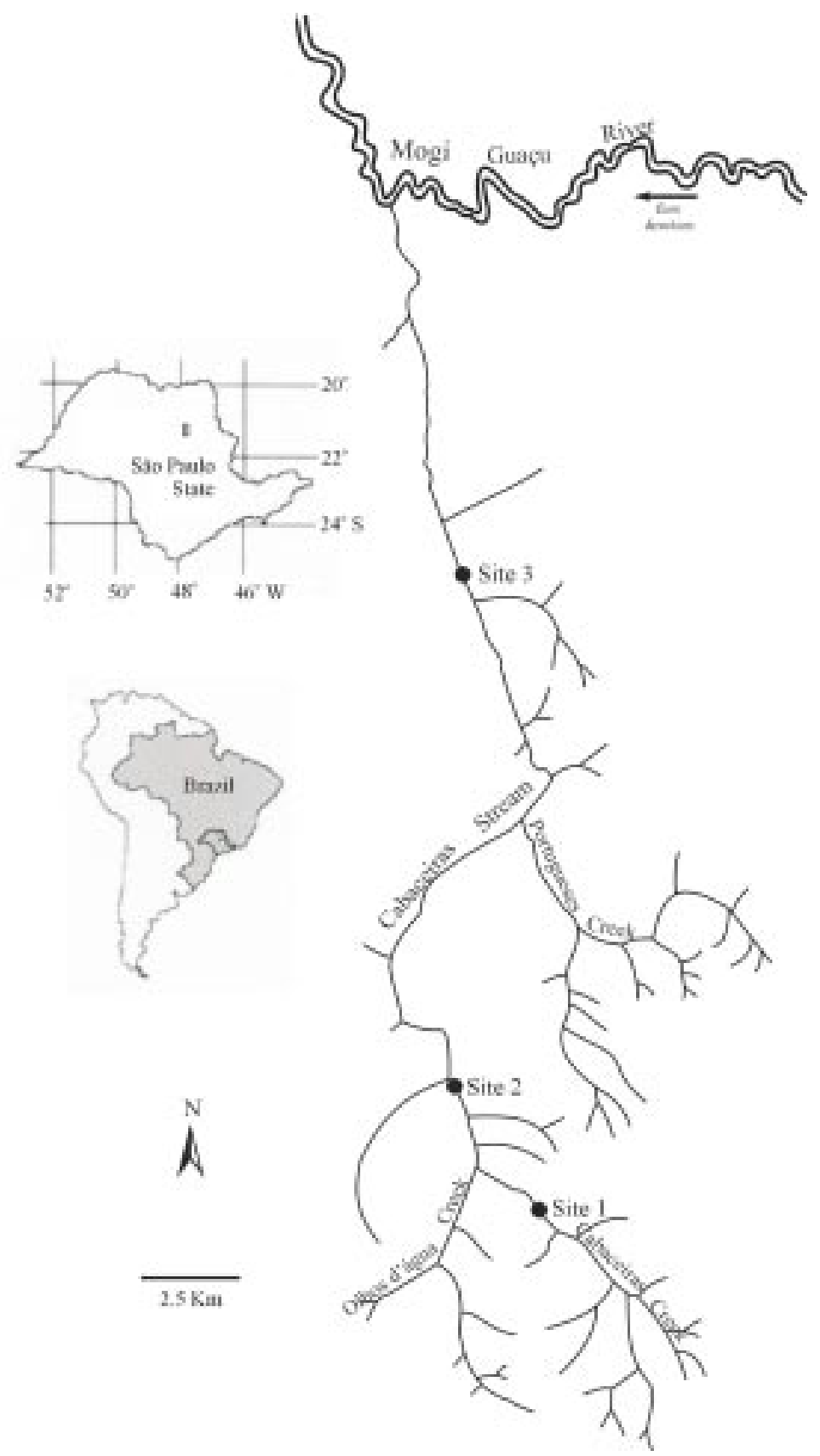

Fig. 1. Collection sites in Cabaceiras Stream, tributary of the Mogi Guaçu river, São Paulo State, Brazil. 
were immediately fixed in $10 \%$ formalin solution and later preserved in $70 \%$ ethanol. At the laboratory fish species were identified, measured (Standard length) and deposited in the fish collection of the Laboratório de Sistemática de Peixes, Departamento de Ecologia e Biologia Evolutiva, Universidade Federal de São Carlos, São Carlos, São Paulo.

The constancy of occurrence method (DAJOz, 1973) aided to identify the resident species, by the followed expression: $c=p_{i} / P \times 100$, where $c$ is the constancy value of the species in interest, $p_{i}$ is the number of collections with the species in interest and $\mathrm{P}$ is the total number of collections performed. The species with $\mathrm{c}>50$ were considered constant, with $25<\mathrm{c}<50$, accessory and with $\mathrm{c}<25$, accidental.

In function of the distinctive species composition encountered in sites 1 and 2 relative to site 3, seasonal patterns in fish species abundance were investigated for the upper, i.e. sites 1 and 2, and lower (site 3) studied stretches. Jaccard similarity index (MAGURRAN, 1991) was applied to verify the similarities patterns among sampled months: $\mathrm{q}=\mathrm{c} /(\mathrm{a}+\mathrm{b}-\mathrm{c}) \mathrm{x} 100$ where, $\mathrm{q}=$ the Jaccard similarity index between samples $\mathrm{A}$ and $\mathrm{B} ; \mathrm{a}=$ the number of species collected at sample $\mathrm{A} ; \mathrm{b}=$ the number of species collected at sample $\mathrm{B}$ and $\mathrm{c}=$ the number of species found in both samples. The index values ranges from 0 , meaning total dissimilarity, to 1 , which means that compared samples are identical on fish species composition. Jaccard similarity values between collected months in upper and lower stretches were used to perform a cluster analysis with NTSYS-PC version 2.02 software, using UPGMA as clustering method. The cophenetic correlation coefficient (r) was calculated to evaluate the deformation of the dendrogram in relation to the original similarity matrix.

\section{RESULTS}

Based on climatological data recorded in São Carlos (fig. 2), total rainfall during the period was $1388.2 \mathrm{~mm}$ and the greater rainfall values were concentrated from December to March months, characterizing the rainy season, initiated in September.

A total of 3403 specimens were collected, distributed into 45 species of fishes, belonging to the orders Characiformes (eight families, 21 genera and 27 species), Siluriformes (three families, 11 genera and 13 species), Gymnotiformes (two families, two genera and two species), Perciformes (one family, two genera and two species) and Synbranchiformes, with a single species (tab. I). Characidae was the most speciose family, with 14 species, followed by Loricariidae and Pimelodidae, with five species each and by Anostomidae with four species. The Callichthyidae family had three species, Erythrinidae, Crenuchidae, Parodontidae and Cichlidae, two and Serrasalmidae, Prochilodontidae, Curimatidae, Gymnotidae, Sternopygidae and Synbranchidae showed only one species each.

Site 1, site 2 and 3 presented 19, 16 and 38 species, respectively (tab. I). Astyanax scabripinnis paranae, Oligosarcus pintoi, Corydoras aeneus and Cetopsorhamdia iheringi occurred in the first sites. Parodon tortuosus and Imparfinis schubarti were represented only at site 1 and Characidium gomesi only at site 2. Astyanax altiparanae, A. fasciatus, Bryconamericus stramineus, Piabina argentea, Characidium cf. zebra, Leporinus friderici acutidens, Hypostomus spp., Hisonotus sp. and Geophagus brasiliensis were species common to the three studied stretches. Collection site 3 presented a distinct fish fauna composition if compared with the upper sites, presenting twenty five exclusive species. Specimens of Erythrinidae, Serrasalmidae, Curimatidae, Prochilodontidae, Gymnotidae, Sternopygidae and Synbranchidae families occurred only at this lower stretch.

The constant fish species, according to the occurrence constancy method, varied among the sampled stretches (tab. I). At site 1: $47.4 \%$ of the species were constant, $26.3 \%$ were accessory and $26.3 \%$ were accidental. At site $2: 62.5 \%$ were constant, $18.7 \%$ were accessory and $18.7 \%$ were accidental. At site $3: 44.7 \%$ of the species were considered 


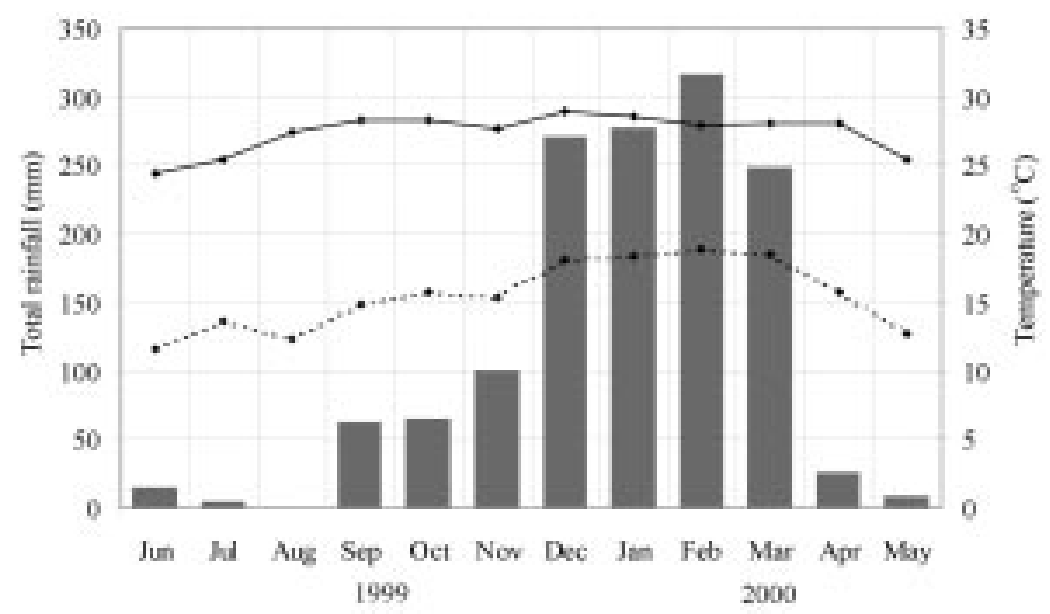

Fig. 2. Total monthly rainfall (bars) and means of the highest (continuous line) and lowest (dotted line) air temperatures registered from June 1999 to May 2000 by the climatological station at Universidade Federal de São Carlos.

constant, $31.6 \%$ accessory and $23.7 \%$ accidental. Astyanax altiparanae, Bryconamericus stramineus, Oligosarcus pintoi, Piabina argentea, Characidium cf. zebra, Corydoras aeneus, Hisonotus sp., Hypostomus sp. A and Geophagus brasiliensis were constant species at site 1. Astyanax scabripinnis paranae and the same constant species at site 1 comprised the constant species at site 2. Twelve of seventeen constant fish species at site 3 were exclusively registered in this lower stretch: Hoplias malabaricus, Hemigrammus marginatus, Hyphessobrycon eques, Moenkhausia sanctaefilomenae, Cheirodon stenodon, Serrapinnus notomelas, Serrasalmus spilopleura, Steindachnerina insculpta, Hoplosternum littorale, Megalechis personata, Eigenmannia sp. and Gymnotus cf. carapo. Astyanax fasciatus was constant only at this site 3 . The constant species common to all three sites were A. altiparanae, C. cf. zebra, Hypostomus sp. A and G. brasiliensis.

On wet season Cabaceiras stream showed 43 species and on dry season 39 species were registered. All the three collection sites presented a greater number of species on wet season (tab. II). The fish species composition did not suffer great seasonal modifications, but the range of standard length for some species were larger on wet season when compared with dry season (tab. II). Young individuals of medium to large sized species Salminus hilarii, Leporinus friderici acutidens, Prochilodus lineatus and Pimelodus maculatus were caught in dry season at the lower site. In the beginning of the rainy season, in November 1999, adults of L. friderici acutidens were captured at the three collection sites and two months later the smallest individuals (young of the year) of this immigrant and other resident species, such as Steindachnerina insculpta, Hoplosternum littorale, Rhamdia quelen and Eigenmannia sp., were caught at the flooded margins of the lower sampled stretch.

Cluster analysis (fig. 3) evidenced two major groups in a similarity value of 0.18 , reflecting the distinct fish fauna composition between the upper (1 and 2) and lower (3) sites. The group formed by the upper stretches samples is divided into two subgroups, 
Table I. Fish species registered from June 1999 to May 2000 in Cabaceiras stream, São Paulo State, Brazil, and classification based on persistence of the species in the collection sites.

\begin{tabular}{|c|c|c|c|}
\hline Taxon & Site 1 & Site 2 & Site 3 \\
\hline \multicolumn{4}{|l|}{ Characiformes } \\
\hline \multicolumn{4}{|l|}{ Erythrinidae } \\
\hline \multirow{2}{*}{\multicolumn{4}{|c|}{ Hoplerythrinus unitaeniatus (Spix \& Agassiz, 1829) }} \\
\hline & & & constant \\
\hline \multicolumn{4}{|l|}{ Characidae } \\
\hline \multicolumn{4}{|l|}{ Tetragonopterinae } \\
\hline Astyanax altiparanae Garutti \& Britski, 2000 & constant & constant & constant \\
\hline Astyanax fasciatus (Cuvier, 1819) & accidental & accessory & constant \\
\hline Astyanax scabripinnis paranae Eigenmann, 1914 & accessory & constant & \\
\hline Bryconamericus stramineus Eigenmann, 1908 & constant & constant & accessory \\
\hline Gymnocorymbus ternetzi (Boulenger, 1895) & & & accessory \\
\hline Hemigrammus marginatus Ellis, 1911 & & & constant \\
\hline Hyphessobrycon eques (Steindachner, 1882) & & & constant \\
\hline Moenkhausia sanctaefilomenae (Steindachner, 1907) & & & constant \\
\hline Oligosarcus pintoi Campos, 1945 & constant & constant & \\
\hline Piabina argentea Reinhardt, 1867 & constant & constant & accidental \\
\hline \multicolumn{4}{|l|}{ Cheirodontinae } \\
\hline \multicolumn{4}{|l|}{ Cheirodon stenodon Eigenmann, 1915} \\
\hline \multicolumn{4}{|l|}{ Serrapinnus heterodon (Eigenmann, 1915) } \\
\hline Serrapinnus notomelas (Eigenmann, 1915) & & & constant \\
\hline \multicolumn{4}{|l|}{$\begin{array}{l}\text { Serrapinnus notomelas (Eigenmann, 1915) } \\
\text { Salmininae }\end{array}$} \\
\hline Salminus hilarii Valenciennes, 1850 & accidental & & accessory \\
\hline \multicolumn{4}{|l|}{ Serrasalminae } \\
\hline Serrasalmus spilopleura Kner, 1858 & & & constant \\
\hline Crenuchidae & & & \\
\hline Characidiinae & & & \\
\hline Characidium cf. zebra Eigenmann, 1909 & constant & constant & constant \\
\hline Characidium gomesi Travassos, 1956 & & accessory & \\
\hline Anostomidae & & & \\
\hline Leporinus friderici acutidens (Valenciennes, 1836) & accessory & accidental & accessory \\
\hline Leporinus lacustris Campos, 1945 & & & accessory \\
\hline Leporinus striatus Kner, 1858 & & & accessory \\
\hline Schizodon nasutus Kner, 1858 & & & accidental \\
\hline Parodontidae & & & \\
\hline Apareiodon affinis (Steindachner, 1879) & & & accidental \\
\hline Parodon tortuosus Eigenmann \& Norris, 1900 & accidental & & \\
\hline Prochilodontidae & & & \\
\hline Prochilodus lineatus (Valenciennes, 1836) & & & accessory \\
\hline Curimatidae & & & \\
\hline Steindachnerina insculpta (Fernandez-Yepez, 1948) & & & constant \\
\hline Siluriformes & & & \\
\hline Pimelodidae & & & \\
\hline Cetopsorhamdia iheringi Schubart \& Gomes, 1959 & accidental & accessory & \\
\hline Imparfinis schubarti (Gomes, 1956) & accidental & & \\
\hline Pimelodella gracilis (Valenciennes, 1836) & & & accidental \\
\hline Pimelodus maculatus Lacépède, 1803 & & & accidental \\
\hline Rhamdia quelen (Quoy \& Gaimard, 1824) & accessory & & accessory \\
\hline Callichthyidae & & & \\
\hline Corydoras aeneus $(\mathrm{Gill}, 1858)$ & constant & constant & \\
\hline Hoplosternum littorale (Hancock, 1828) & & & constant \\
\hline Megalechis personata (Ranzani, 1841) & & & constant \\
\hline Loricariidae & & & \\
\hline Hypoptopomatinae & & & \\
\hline Hisonotus sp. & constant & constant & accessory \\
\hline Hypostominae & & & \\
\hline Hypostomus sp. A & constant & constant & constant \\
\hline Hypostomus sp. B & accessory & accidental & accidental \\
\hline Hypostomus sp. C & accessory & accidental & accessory \\
\hline Loricariinae $\mathrm{T}$ t & & & \\
\hline Rineloricaria latirostris (Boulenger, 1900) & & & accidental \\
\hline Gymnotiformes & & & \\
\hline Gymnotidae & & & \\
\hline Gymnotus cf. carapo Linnaeus, 1758 & & & constant \\
\hline Sternopygidae & & & \\
\hline Eigenmannia sp. & & & constant \\
\hline Perciformes & & & \\
\hline Cichlidae & & & \\
\hline Crenicichla sp. & & & accessory \\
\hline Geophagus brasiliensis (Quoy \& Gaimard, 1824) & constant & constant & constant \\
\hline Synbranchiformes & & & \\
\hline Synbranchidae & & & \\
\hline Synbranchus marmoratus (Bloch, 1795) & & & accidental \\
\hline Total of species & 19 & 16 & 38 \\
\hline
\end{tabular}


Table II. Standard length amplitude of the species at the collection sites in Cabaceiras stream, São Paulo State, Brazil, on dry (June to October 1999; April and May 2000) and wet (November 1999 to March 2000) seasons.

\begin{tabular}{|c|c|c|c|c|c|c|c|}
\hline \multirow{3}{*}{ Species } & \multicolumn{7}{|c|}{ Standard length (mm) } \\
\hline & \multirow[b]{2}{*}{$\mathrm{n}$} & \multicolumn{2}{|c|}{ Site 1} & \multicolumn{2}{|c|}{ Site 2} & \multicolumn{2}{|c|}{ Site 3} \\
\hline & & Dry & Wet & Dry & Wet & Dry & Wet \\
\hline Hoplerythrinus unitaeniatus & 10 & & & & & $142-179$ & $82-174$ \\
\hline Hoplias malabaricus & 33 & & & & & $61-248$ & $35-241$ \\
\hline Astyanax altiparanae & 122 & $65-110$ & $76-119$ & $91-112$ & $70-115$ & $27-108$ & $15-111$ \\
\hline Astyanax fasciatus & 145 & & $30-75$ & 31 & 42 & $19-100$ & $17-91$ \\
\hline Astyanax scabripinnis paranae & 56 & $29-58$ & 36 & $19-46$ & $21-37$ & & \\
\hline Bryconamericus stramineus & 397 & $29-51$ & $21-52$ & $16-52$ & $21-51$ & $21-31$ & $16-37$ \\
\hline Gymnocorymbus ternetzi & 11 & & & & & $29-42$ & $31-34$ \\
\hline Hemigrammus marginatus & 34 & & & & & $14-31$ & $20-29$ \\
\hline Hyphessobrycon eques & 347 & & & & & $12-32$ & $13-30$ \\
\hline Moenkhausia sanctaefilomenae & e 106 & & & & & $25-56$ & $20-51$ \\
\hline Oligosarcus pintoi & 81 & $33-72$ & $18-82$ & $29-78$ & $19-65$ & & \\
\hline Piabina argentea & 574 & $23-70$ & $18-74$ & $20-55$ & $19-54$ & & $20-64$ \\
\hline Cheirodon stenodon & 246 & & & & & $19-29$ & $21-29$ \\
\hline Serrapinnus heterodon & 6 & & & & & $22-28$ & $18-25$ \\
\hline Serrapinnus notomelas & 285 & & & & & $18-27$ & $16-26$ \\
\hline Salminus hilarii & 6 & & 166 & & & $188-197$ & $162-204$ \\
\hline Serrasalmus spilopleura & 6 & & & & & $50-70$ & 24-98 \\
\hline Characidium cf. zebra & 78 & $31-55$ & $37-66$ & $33-74$ & $17-45$ & $18-37$ & $13-37$ \\
\hline Characidium gomesi & 4 & & & $40-51$ & $55-56$ & & \\
\hline Leporinus friderici acutidens & 32 & & $136-217$ & & $126-169$ & 74 & $22-238$ \\
\hline Leporinus lacustris & 4 & & & & & $76-82$ & $78-102$ \\
\hline Leporinus striatus & 10 & & & & & $44-103$ & $48-97$ \\
\hline Schizodon nasutus & 3 & & & & & & 188 \\
\hline Apareiodon affinis & 1 & & & & & & 111 \\
\hline Parodon tortuosus & 1 & & 59 & & & & \\
\hline Prochilodus lineatus & 3 & & & & & $81-119$ & 132 \\
\hline Steindachnerina insculpta & 20 & & & & & $54-109$ & $15-104$ \\
\hline Cetopsorhamdia iheringi & 7 & 36 & & $33-72$ & 22 & & \\
\hline Imparfinis schubarti & 1 & 79 & & & & & \\
\hline Pimelodella gracilis & 3 & & & & & & $90-120$ \\
\hline Pimelodus maculatus & 1 & & & & & 118 & \\
\hline Rhamdia quelen & 12 & & $19-102$ & & & $61-103$ & $22-131$ \\
\hline Corydoras aeneus & 144 & $28-48$ & $36-51$ & $25-49$ & $36-49$ & & \\
\hline Hoplosternum littorale & 17 & & & & & $111-137$ & $33-151$ \\
\hline Megalechis personata & 14 & & & & & 51-102 & $14-116$ \\
\hline Hisonotus sp. & 238 & $18-34$ & $15-36$ & $23-34$ & $18-34$ & $22-28$ & 19 \\
\hline Hypostomus sp. A & 184 & $22-85$ & $16-88$ & $26-85$ & $16-101$ & $56-116$ & $15-121$ \\
\hline Hypostomus sp. B & 7 & 125 & $101-139$ & $52-106$ & & 88 & \\
\hline Hypostomus sp. C & 10 & 83 & $42-64$ & & 87 & $88-97$ & $92-119$ \\
\hline Rineloricaria latirostris & 1 & & & & & & 111 \\
\hline Gymnotus cf. carapo & 19 & & & & & $87-223$ & $35-326$ \\
\hline Eigenmannia sp. & 10 & & & & & $83-184$ & $18-218$ \\
\hline Crenicichla sp. & 5 & & & & & $85-155$ & 67 \\
\hline Geophagus brasiliensis & 107 & $23-114$ & $19-135$ & $32-66$ & $14-148$ & $24-144$ & $12-133$ \\
\hline Synbranchus marmoratus & 2 & & & & & & 84 \\
\hline Total of species & 45 & 14 & 17 & 14 & 15 & 32 & 36 \\
\hline Total of individuals & 3403 & 647 & 499 & 362 & 284 & 847 & 764 \\
\hline
\end{tabular}


one with the driest and other with the rainy months, that represents the seasonal influence over the species composition. Lower site did not evidenced this seasonality in fish species composition, presenting a mixture of dry and rainy months with similarities values below those values encountered in the upper sites. The cophenetic correlation coefficient value $(r=0.949)$ indicated a satisfactory representation of the similarity matrix in the dendrogram.

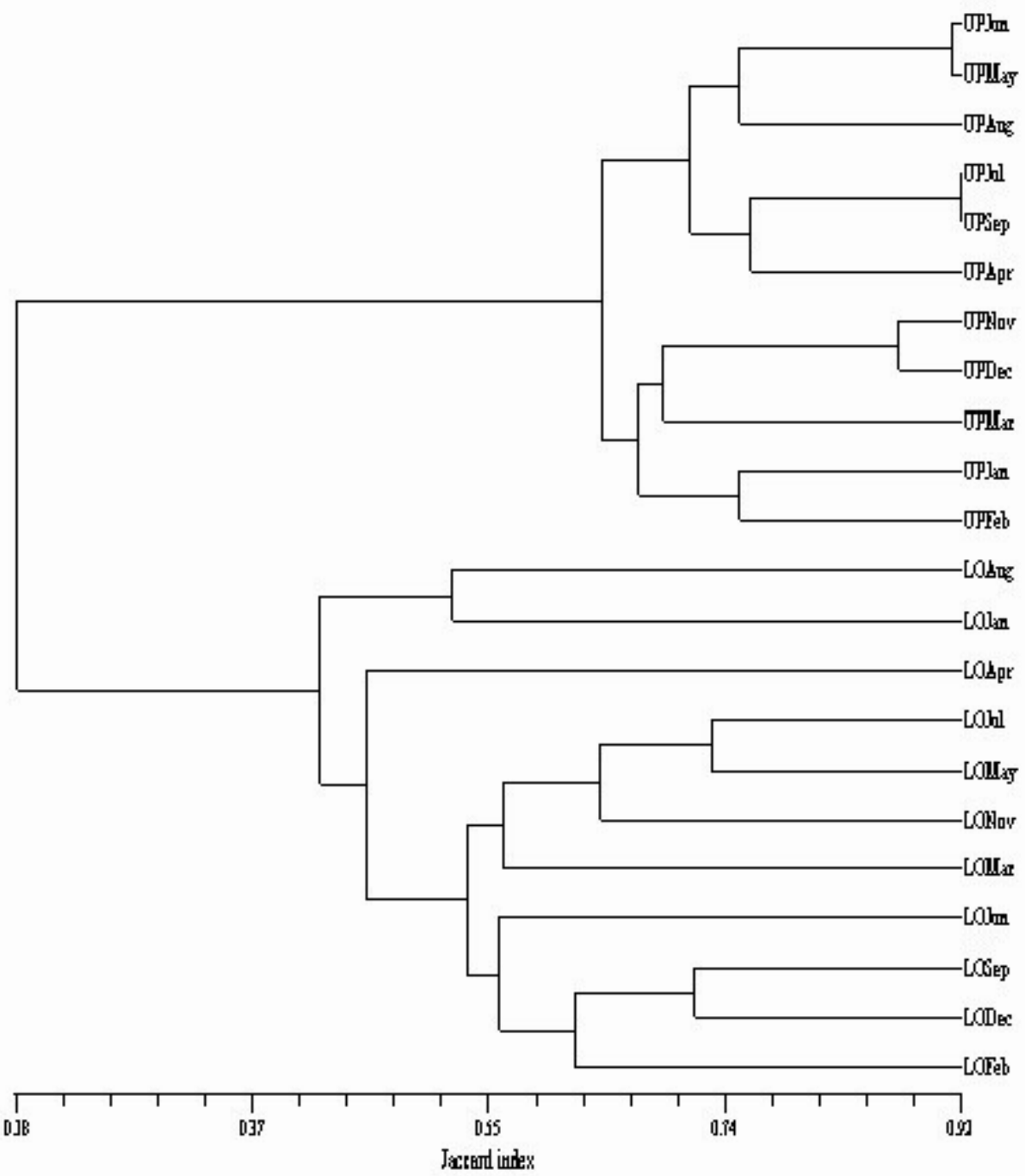

Fig. 3. Dendrogram resulted from the cluster analysis with the similarities values between months in upper (UP) and lower (LO) sampled stretches $(r=0.949)$. 


\section{DISCUSSION}

The Cabaceiras stream showed predominance of species belonging to the orders Characiformes and Siluriformes, and presence of Gymnotiformes, Perciformes and Synbranchiformes, reflecting what has been registered for neotropical freshwater fish communities. The South America fish fauna is predominantly composed by species of Ostariophysi superorder, from which the Characiformes and Siluriformes orders exhibit major diversity, besides the Gymnotiformes. CASTRO \& CASATTI (1997) also related a high predominance of those two first fish orders in a stream of Pardo river, of the Mogi Guaçu river system. CASATTI et al. (2001) found predominance of Siluriformes order in number of fish species in streams of Paranapanema river, upper Paraná basin.

Fish species composition of Cabaceiras stream comprised resident and transient species assemblages, which could be defined by the aid of occurrence constancy method. According to this method the constant species in at least one of the sites studied may be considered part of the resident ichthyofauna of high Paraná streams. UIEDA (1984), studying a fish fauna from a stream of Tietê river, considered constant species as residents, while accessory and accidental species were considered the immigrant fauna. In Cabaceiras stream, resident assemblage is composed by small fish species characteristics from creek environments as A. scabripinnis paranae, O. pintoi, C. aeneus and Hisonotus sp., which were collected at upper stretches, and includes some broader distributed species able to explore other environments with high water volume of the floodplain system, as $A$. altiparanae, A. fasciatus, Hypostomus spp. and G. brasiliensis, species found in the three studied sites. Species of fish families that were not registered in those upper sites are among the persistent species assemblage found in site 3, as the erythrinid Hoplias malabaricus, the curimatid Steindachnerina insculpta and the gymnotiforms Gymnotus cf. carapo and Eigenmannia sp.

Some species with constancy lower than $50 \%$ found at the three sites probably are also persistent species. Occurrence in low frequency, perhaps due to a natural scarcity of these species individuals in the stream waters, are under influence of the selectivity of used fishing equipment. According to GARUTTI (1988), the constancy of species is strongly related with seasonal changes in environmental factors, with the number of individuals in shoals, individuals or shoals movement and the period activity of each species. At Cabaceiras stream, persistent species at the upper stretches with less than $50 \%$ of constancy were $C$. gomesi, $C$. iheringi and I. schubarti, species typical of stream environments. The erythrinid Hoplerythrinus unitaeniatus, pimelodids $R$. quelen and Pimelodella gracilis, the cichlid Crenicichla sp. and synbranchid S. marmoratus are examples of those persistent species, with few occurrence, which were presented only at the lower stretch.

The low similarity of the ichthyofauna between the upper and lower sites showed that Cabaceiras stream cover for distinct resident fish assemblages at each stretch. PENCZAK et al. (1994) encountered fewer species in the headwater sites in comparison with sites located in the middle and lower regions of two streams at Paraná river basin. GARUTTI (1988) studying the longitudinal distribution of a stream fish fauna registered a pattern of increase of species abundance from source to mouth of the Barra Funda stream. This greater species richness verified in the streams lower stretches of floodplain rivers is possibly due to distinct physical and biological features exhibited by these environments with high water volume relative to upper stretches, areas of flooded vegetation and, 
consequently, available refuges for resident fish species, in addition to the invasion of immigrant fish species from subjacent areas. Although the upper stretches of these tributaries also present spatial heterogeneity in function of pools intercalated with riffles or runs habitats, this sort of environments are just available to be colonized by small sized fish species with different morphological attributes.

In Cabaceiras stream longitudinal variation in species richness was reflected in the trophic arrangement of the studied sites. Species registered in the upper stretches are known to be predominantly omnivores, as some small characids, insect feeders, as pimelodids, or algivorous, as the loricariids. At site three, in addition to these functional trophic units registered, the resident fish assemblage presented some piscivorous species, as Hoplias malabaricus, Hoplerythrinus unitaeniatus and S. spilopleura, and some detrivorous benthic feeders, as $S$. insculpta, showing a different trophic structure when compared to upper sites, where only one specimen of the piscivorous fish species Salminus hilarii was collected.

Longitudinal migration movements of large fish species are well documented for Mogi Guaçu river. SCHUBART (1954) registered characid, anostomid and prochilodontid fish species migrating upriver at the beginning of the wet season, to reach the Cachoeira de Emas, at upper Mogi Guaçu, and spawning between November and late January. Godoy (1954) mentioned that the oxbow lakes of Mogi Guaçu river floodplain serve as breeding places for migratory fish species. The eggs and larvae of these fishes, which adults had spawned in the river channel, are lanced to the lagoons when the water level is high and marginal areas are flooded. GALETTI et al. (1990) also found evidences that these lenthic environments are nursery areas, providing refuges for young individuals of fish species. EsTEVES et al. (2000) found predominance of lenthic species in three oxbow lakes, proposing that, in function of environmental impacts, the role of these environments as breeding places for migratory fishes should be revised.

According to Lowe-MCConNell (1979), tropical continental waters present seasonality in function of rainfall and flooding periods. The presence of young individuals of P. lineatus, S. hilarii, L. friderici acutidens, L. lacustris, P. maculatus in both seasons and adults of $L$. friderici acutidens only on wet season, at all studied stretches, suggests that Cabaceiras stream is also explored by adults of species which perform lateral migration in the floodplain to spawn, and as a recruitment place for juveniles. The lateral gradient of floodplain rivers presents fishes with a tremendous diversity of options for habitat selection (WINEMILLER \& JEPSEN, 1998). Bank vegetation seasonally flooded provides shelter and refuge to small juveniles of both, migratory and non migratory fish species. The immigrant fish species seem to have their distribution influenced by climatic seasonality, which promote expansion and retraction of tropical streams in rainy and dry seasons. In Cabaceiras stream fish movements upstream were observed in the beginning of the rainy season, before flood. The principal species that performed this lateral migration was $L$. friderici acutidens, which reach the upper sites. Some evidences of this upstream movement to spawn are represented by the collection of young of the year individuals, when the margins at site 3 were flooded.

The influence of climatic seasonality in tropical fish biology was discussed by Lowe-McConnell (1999) for the Amazonas and by Winemiller \& JEPSEN (1998) for the Orinoco systems. There, fish movements were associated with modifications on water level during the cyclic flooding, which can occur once or twice a year. The flooded areas 
are occupied and explored by fishes during these wet seasons and, according to WiNEMILLER \& JEPSEN (1998), fishes leave ephemeral flooded habitats moving to more permanent water bodies when floodplains gradually dry. Seasonal modifications on fish species composition and distribution at Cabaceiras stream were detected through the occurrence and standard length range analysis of the species in each season. As showed in the cluster analysis, the upper stretch of the stream suffered greater seasonal changes in fish species composition relative to the lower stretch, where seasonality was mostly reflected in standard length range of a variety of persistent and non persistent species. Low declivity exhibited by Cabaceiras stream is one important factor that should be considered as promoter of seasonal patterns on fish assemblage composition, allowing free fish movement from the Mogi Guaçu river channel to the upper portion of its drainage.

Despite nowadays occupied by agricultural activities, including the use of water for irrigation and the use of agricultural chemical agents, as well as the elimination of part of riparian vegetation, Cabaceiras stream exhibits a representative stream fish fauna of the high Paraná basin. Other water bodies tributaries of Mogi Guaçu river basin as Cabaceiras still shelter small sized resident fish species, providing a sort of environments seasonally available for exploration by the larger sized species. These environments should be preserved for conservation of this little known resident fish assemblages and also to preserve some breeding areas for the migratory fish species.

Acknowledgments. To all people who helped in field work and fish arrangements in laboratory. Pedro Manoel Galetti, José Roberto Verani and Orlando Moreira Filho (UFSCar) and Francisco Langeani Neto (UNESP) have read the manuscript and made useful suggestions. To Kirk O. Winemiller (Texas A\&M University) for criticism and suggestions. To CNPq for provide continuing grant to the junior author, and for provide, through the Programa de Pós-Graduação em Ecologia e Recursos Naturais, a grant to the senior author.

\section{REFERENCES}

Casatti, L.; Langeani, F. \& Castro, R. M. C. 2001. Peixes de riacho do Parque Estadual Morro do Diabo, bacia do alto rio Paraná, SP. Revta Biota Neotropica, Campinas, 1(1-2):1-15.

Castro, R. M. C. \& Casatti, L. 1997. The fish fauna from a small forest stream of the upper Paraná river basin, southeastern Brazil. Ichthyol. Explor. Freshwaters, München, 7(4):337-352.

DAJOZ, R. 1973. Ecologia Geral. São Paulo, EDUSP. 474p.

Esteves, K. E. \& Galetti, P. M., JR. 1995. Food partitioning among some characids of a small Brazilian floodplain lake from the Paraná river basin. Environ. Biol. Fishes, Dordrecht, 42:375-389.

Esteves, K. E.; Sendacz, S. et al. 2000. Características físicas, químicas e biológicas de três lagoas marginais do rio Mogi-Guaçu (SP) e avaliação do seu papel como viveiro natural de espécies de peixes reofílicos. Bolm Inst. Pesca, São Paulo, 26(2):169-180.

Galetti, P. M., JR.; Esteves, K. E. et al. 1990. Aspectos comparativos da ictiofauna de duas lagoas marginais do rio Mogi-Guaçu (alto Paraná, Estação Ecológica do Jataí, SP). Acta limnol. Bras., São Carlos, 3:865-885.

GarutTI, V. 1988. Distribuição longitudinal da ictiofauna em um córrego da região noroeste do estado de São Paulo, bacia do rio Paraná. Revta bras. Biol., Rio de Janeiro, 48(4):747-759.

Godoy, M. P. 1954. Locais de desova de peixes num trecho do rio Mogi Guaçu, Estado de São Paulo, Brasil. Revta bras. Biol., Rio de Janeiro, 14(4):375-396.

1962. Marcação, migração e transplantação de peixes marcados na bacia do rio Paraná superior.

Arq. Mus. nac. Rio de J., Rio de Janeiro, 52:105-113.

Lowe-McConnell, R. H. 1979. Ecological aspects of seasonality in fishes of tropical waters. Symp. zool. Soc. Lond., London, 44:219-241.

1999. Estudos ecológicos em comunidades de peixes tropicais. São Paulo, EDUSP. 536p. 
Luiz, E. A.; Agostinho, A. A. et al. 1998. Ecologia trófica de peixes em dois riachos da bacia do rio Paraná. Revta bras. Biol., Rio de Janeiro, 58(2):273-285.

MagurRan, A. E. 1991. Ecological diversity and its measurement. New York, Chapmann \& Hall. $179 \mathrm{p}$.

Meschiatti, A. J. 1995. Alimentação da comunidade de peixes de uma lagoa marginal do rio Mogi Guaçu, SP. Acta limnol. Bras., São Paulo, 7:115-137.

Pavanelli, C. S. \& Caramaschi, É. P. 1997. Composition of the ichthyofauna of two small tributaries of the Paraná river, Porto Rico, Paraná State, Brazil. Ichthyol. Explor. Freshwaters, München, 8 (1):23-31.

Penczak, T.; Agostinho, A. A. \& Okada, E. K. 1994. Fish diversity and community structure in two small tributaries of the Paraná River, Paraná State, Brazil. Hydrobiologia, Ghent, 294(3):243-251.

Schubart, O. 1954. A piracema no rio Mogi Guassú (Estado de São Paulo). Dusenia, Curitiba, 5 (1):49-59.

Uieda, V. S. 1984. Ocorrência e distribuição dos peixes em um riacho de água doce. Revta bras. Biol., Rio de Janeiro, 44(2):203-213.

Winemiller, K. O. \& Jepsen, D. B. 1998. Effects of seasonality and fish movement on tropical river foodwebs. J. Fish Biol., London, 53(Supplement A):267-296.

Recebido em 11.06.2002; aceito em 14.11.2002.

Iheringia, Sér. Zool., Porto Alegre, 93(2):127-138, 30 de junho de 2003 